\title{
PROVIDING THE THERMAL RELIABILITY OF WINDOW JUNCTIONS DURING THE THERMAL MODERNIZATION OF CIVIL BUILDINGS
}

Scientific paper

\section{Mykola Pashynskyi}

(Received: 23 June 2020; accepted: 23 September 2020)

Department of building, road machines and construction, Central Ukrainian National Technical University, Kropyvnytskyi, PhD, Senior lecturer.

Corresponding author: filonalone@gmail.com

\section{Stanislav Dzhyrma}

Department of building, road machines and construction, Central Ukrainian National Technical University, Kropyvnytskyi, PhD, Assoc. prof.

\section{Victor Pashynskyi}

Department of building, road machines and construction, Central Ukrainian National Technical University, Kropyvnytskyi, Sc. D., prof.

Vladislav Nastoyashchiy

Department of building, road machines and construction, Central Ukrainian National Technical University, Kropyvnytskyi, PhD., prof.

\begin{abstract}
In order to assess the possibility of condensation on an internal window jamb surface, the temperature fields of window junctions to brick and precast concrete walls of civil buildings were analyzed, which were massively produced in the second half of the twentieth century. This study obtained the dependences of the jamb temperature on the thickness of the additional insulation layer and the outdoor temperature. Additionally, it showed the possibility of adjusting the jamb temperature by shifting the window frame inside the building. Outside air temperatures at which no condensation will occur in the initial junction structures and after thermal modernization by additional facade insulation were determined. The results can be used to replace worn-out windows and during the thermal modernization of buildings.
\end{abstract}

Keywords: Brick walls; precast concrete walls; thermal modernization; block frame window; condensation. 


\section{INTRODUCTION}

In the second half of the twentieth century, residential buildings were massively erected in the European territory of the USSR and in the countries of Eastern Europe. They had three types of walls: brick walls $510 \mathrm{~mm}$ thick, walls made of large expanded clay blocks about $400 \mathrm{~mm}$ thick, and large-panel structures made of expanded clay aggregate 300-350 mm thick. In all the cases, wooden windows were used. Valid at the time, the requirements for heat transfer resistance of the walls (about $1 \mathrm{~m}^{2} \cdot \mathrm{K} / \mathrm{W}$ ) were several times less than the modern requirements for the territory of Ukraine (2.8-3.3 $\left.\mathrm{m}^{2} \cdot \mathrm{K} / \mathrm{W}\right)$ [1]. In addition to the high consumption of thermal energy for heating, in areas of increased heat transfer of such walls, a condensate is often formed owing to the temperature drop below the dew point. One of such zones is the junction of a window to a wall, where periodic soaking with condensate causes the failure of a block frame window. In order to increase energy efficiency, thermal modernization of such buildings is carried out, which usually pertains to the installation of external facade insulation and the replacement of the block frame windows with modern PVC structures with double-glazed windows.

The requirements and methods for ensuring thermal reliability are presented in [1-3], and the energy-saving potential by creating passive houses was considered in [2, 4]. A key factor in ensuring thermal reliability is the thickness of the insulation layer, which depends on its thermal conductivity, energy efficiency requirements, and climatic conditions. Mineral wool, which has a fairly low thermal conductivity and high technological and operational characteristics, is most often used as a heat-insulating material. For example, mineral wool of Rockwool brand has an estimated thermal conductivity of $0.035 \mathrm{~W} /(\mathrm{mK})[5,6]$.

The current requirements for the insulation of civil buildings walls and the division of European countries into climatic zones are analyzed in $[7,8]$. A generalization of the requirements for the thermal insulation of walls showed that in the countries of Southern Europe (Italy, Spain, Greece, etc.), the mineral wool insulation layer thickness is close to $50 \mathrm{~mm}$. Moreover, in the middle region (Ukraine, Poland, Germany, France, etc.), it is approximately $100 \mathrm{~mm}$, approaching in some cases up to $150 \mathrm{~mm}$. Considerable attention is paid to establishing the optimal thickness of the thermal insulation of enclosing structures based on the minimum total costs for construction and heating [9-11], as well as the minimum environmental impact [8, 12], in particular the minimization of carbon dioxide emissions.

Climatic conditions of operation are defined by the temperature of atmospheric air and also by the temperature and humidity of air indoors. According to [13 p. 73], where the national annexes to the standards are summarized [14], it was found that the winter design temperatures of atmospheric air in European countries (with the exception of Scandinavia with a particularly cold climate) vary from $0{ }^{\circ} \mathrm{C}$ to $-40{ }^{\circ} \mathrm{C}$. In particular in Ukraine, which is located in the middle latitudinal strip, the temperatures of the coldest five-day period for calculating the thermal conductivity of walls vary from $-7^{\circ} \mathrm{C}$ to $-28^{\circ} \mathrm{C}[15]$.

The indoor air temperature is set by the national standards depending on the purpose of the premises, ranging from $+18{ }^{\circ} \mathrm{C}$ to $+22{ }^{\circ} \mathrm{C}$, and for non-residential premises, it can be slightly lower $\left(+14^{\circ} \mathrm{C}\right.$ or $\left.+16^{\circ} \mathrm{C}\right)[16]$. The humidity of the indoor air in residential and office premises can vary from $50 \%$ to $55 \%$. Different combinations of air temperature and humidity within the specified limits determine the temperature of the dew point in residential and office premises from $7.4^{\circ} \mathrm{C}$ to $12.6^{\circ} \mathrm{C}$.

Matching a given class of energy efficiency is ensured by a complex set of architectural and structural solutions, including sufficient insulation of enclosing structures. Usually, this guarantees the fulfillment of other requirements for thermal reliability: the permissible difference between the temperatures of the indoor air and the surface, as well as the absence of condensation on the inner surfaces of walls. The junctions of enclosing structures have zones of increased heat transfer; therefore, they can be problematic. One of such unreliable junctions is the connection of a window frame to a wall, where increased heat loss occurs, and moisture can condense on the surface of the window jamb when the temperature of the inner surface of the wall is below the dew point.

The impact of the position of a window in a cavity wall and in a building envelope was examined in [17-20]. In [17], the influence of window orientation (north, east, south, west) and window position (center, upper, bottom left and right) was analyzed. The influence of the junction design of a block frame window to precast concrete wall on the heat loss and the temperature fields was studied in [18]. It was shown that the heat loss and temperature distribution in the junctions can be controlled by adding additional insulation or by shifting the window to a cavity 
wall. Analysis of five types of nodes at two positions of the block frame window showed that the design of the window junction significantly affects the heat loss, position of the zero-degree isotherm, and possibility of condensation on the inner surface.

In [20], the authors studied in more detail the influence of the window position in a cavity wall on the temperature of the inner surface and the possibility of condensation. The dependence of the internal window jamb temperature on the position of the window in a brick wall with a thickness of $510 \mathrm{~mm}$ at a given temperature of atmospheric air was set. The resulting graph allowed to set the position of the window at which the surface temperature of the internal jamb exceeds the dew point temperature.

In general, $[18,20]$ showed that the position of a window frame in a cavity wall can affect the surface temperature of the internal window jamb and the possibility of condensation in this zone. This effect can be used during the thermal modernization of different types of walls operating in various climatic conditions. For this purpose, it is necessary to analyze the temperature mode of operation of window frame junctions to walls.

The purpose of this study is to develop recommendations for full-frame window installation during the thermo-modernization of existing walls. These at a given outdoor air temperature will ensure the temperature of an internal window jamb is not lower than the dew point and exclude the possibility of condensation in areas where a window adjoins a wall.

\section{WALLS AND JUNCTION DESIGN}

This study analyzes the wall junctions used in the practice of housing and public construction in the second half of the last century. Sketches of these nodes are shown in Figures 1 and 2. The designations of the junction elements with the corresponding thermal characteristics of the used materials are given in Table 1.

Figure 1 shows the walls in their original conditions. The brick wall with a thickness of $510 \mathrm{~mm}$ is made of solid bricks, and the internal plaster with a thickness of $20 \mathrm{~mm}$ is made of lime-sand mortar. The windows have an outside brick casing with dimensions of $120 \times 65 \mathrm{~mm}$ (Figs. 1 and 2, mark 10). The precast concrete wall with a thickness of $300 \mathrm{~mm}$ is made of expanded clay concrete with an internal plaster of lime-sand mortar $(20 \mathrm{~mm}$ thick). In the initial position, the window frame was installed almost close to the outside brick casing (with a gap of $10-15 \mathrm{~mm}$ ) or at a distance $X=25-50 \mathrm{~mm}$ from the outer surface of the precast concrete wall. The external jamb in the precast concrete wall is formed from cement-sand mortar. In both cases, the window can be shifted into a room during window frame replacement by an amount $X$. The gap formed between the window and the outside brick casing is filled with a plate of mineral wool or expanded polystyrene.
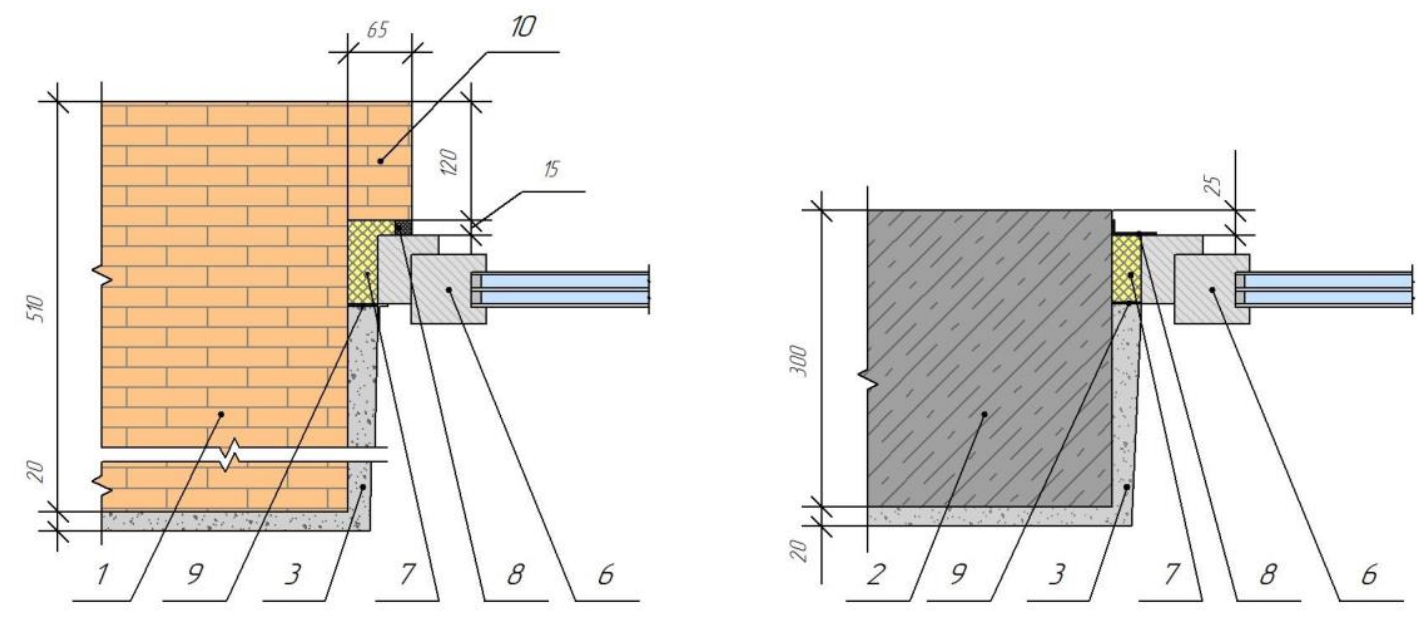

Figure 1 Window frame junction to brick and panel walls without additional insulation

Figure 2 shows the studied wall structures after thermal modernization. They have a mineral wool facade insulation with a thickness of $B=50 \mathrm{~mm}, B=100 \mathrm{~mm}$, or $B=150 \mathrm{~mm}$. When the window is displaced inside the room, the gap between it and the brick wall casing is filled with mineral wool. The outer jamb of the precast 
concrete wall is insulated with a 50-mm mineral wool plate. The amount, $X$, of displacement of the window frame inside the room is measured as shown in Figure 2.
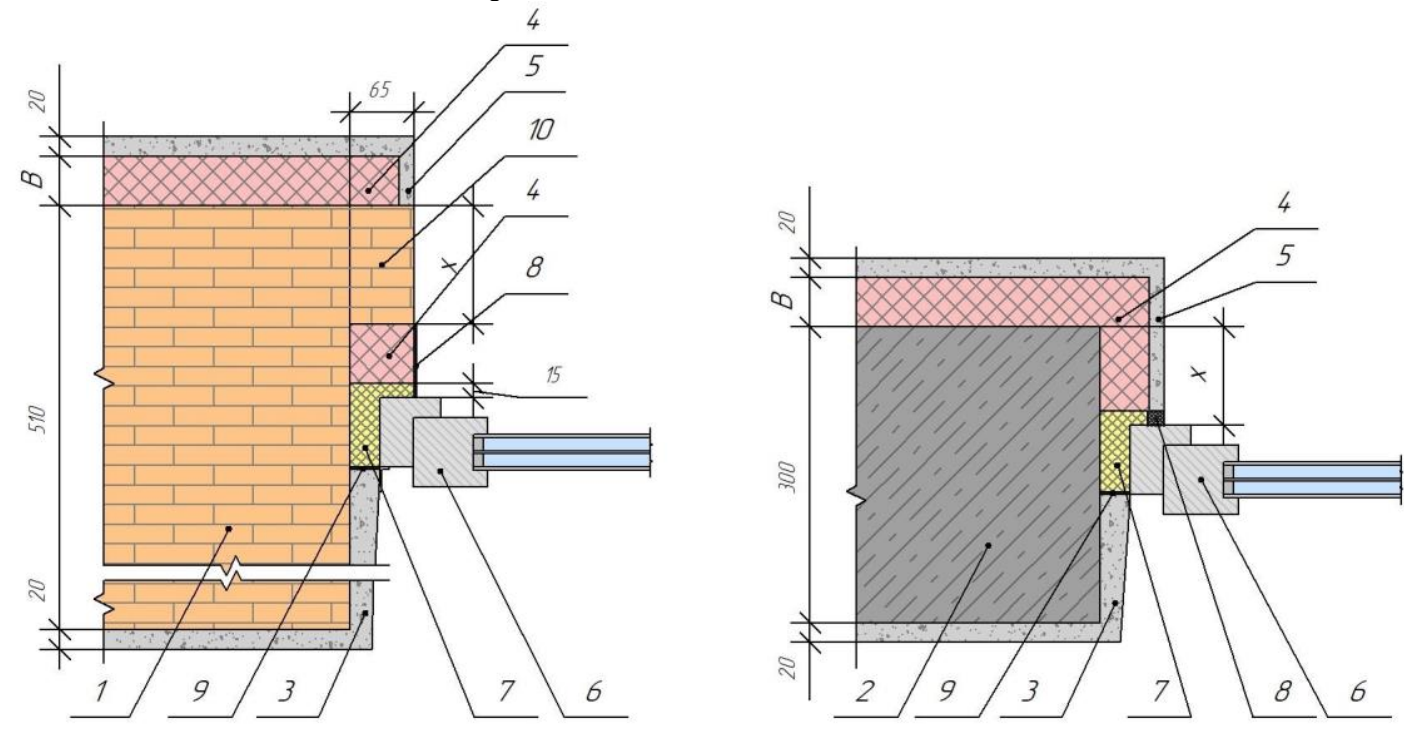

Figure 2 Window frame junction to brick and precast concrete walls with additional facade insulation

In all the cases, 70-mm metal-plastic double-glazed REHAU windows with a five-chamber plastic profile are analyzed. Each window is installed at a distance $X \mathrm{~mm}$ from the starting position, as shown in Figure 1. Sealing from the side of the room is made of vapor-proof materials (vapor barrier tapes, aerosol sealants, thermal insulating films), the central thermal insulation section is made of mounting foam, and the external insulation is made of vapor-permeable waterproof materials. The internal jambs are made of lime-sand plaster.

The thermal characteristics of the materials required for the temperature analysis of the junctions are determined according to the current design norms, technical conditions for the materials, and reference books. The characteristics of the materials that were taken into account for further analysis are listed in Table 1.

Table 1 Thermal characteristics of materials

\begin{tabular}{clcc}
\hline $\begin{array}{c}\text { Designations } \\
\text { in the figures }\end{array}$ & \multicolumn{1}{c}{ Materials } & $\begin{array}{c}\text { Density } \mathbf{\rho} \\
{\left[\mathrm{kg} / \mathrm{m}^{2}\right]}\end{array}$ & $\begin{array}{c}\text { Thermal } \\
\text { conductivity } \boldsymbol{\Lambda} \\
{[\mathrm{W} /(\mathrm{mK})]}\end{array}$ \\
\hline 1 & Solid ceramic brick masonry & 1800 & 0.810 \\
2 & Precast expanded clay concrete wall & 1000 & 0.410 \\
3 & Lime-sand mortar & 1600 & 0.810 \\
4 & Rockwool mineral wool insulation & 135 & 0.035 \\
5 & Cement-based composite plaster & 1800 & 0.930 \\
6 & PVC window & - & 0.350 \\
7 & Polyurethane foam & 25 & 0.033 \\
8 & Waterproof vapor permeable gasket & 150 & 0.050 \\
9 & Vapor barrier insulation & - & - \\
10 & Brick casing & 1800 & 0.810 \\
\hline
\end{tabular}

\section{METHOD FOR STUDYING THE TEMPERATURE REGIME OF JUNCTIONS}

The analysis of the temperature regime of the above described junctions was performed by the finite element method modeling in the THERM [21] program environment, developed at the University of California. Based on the junction design, thermal characteristics of the used materials, and outdoor and indoor air 
temperatures, the program allows obtaining the temperature field of a junction in the form of isotherms as well as temperatures at specified points. Previously performed calculations showed that the lowest temperature of the inner surface of the walls is observed in the above described junctions of the window frame to the internal jamb.

To obtain the temperature dependences at the critical point from the wall structure, calculations of the position of the window frame and the temperature of the outside air were performed for different combinations of these factors. Indoor air temperature $t_{i n}=+20^{\circ} \mathrm{C}$ taken equal to the average value for different countries and premises of various purposes. According to [13], outdoor temperatures were taken in the range from $t_{\text {out }}=0^{\circ} \mathrm{C}$ to $t_{\text {out }}=-40^{\circ} \mathrm{C}$ with an interval of $5^{\circ} \mathrm{C}$. This temperature range covers all the European countries with the exception of colder Scandinavia. The thermal characteristics of the materials are taken according to Table 1.

As a result of the calculations, the tabular dependences of the inner jamb temperature of the critical point on nine values of the outside air temperature and on the placement of the block frame window in a cavity wall were obtained. The location of the window frame is specified by the distance, $X$, indicated in Figure 2 from the initial position of the window from Figure 1.

The calculations were performed for the two aforementioned types of wall structures with three thicknesses of the insulating layer: $B=50 \mathrm{~mm}, B=100 \mathrm{~mm}$, and $B=150 \mathrm{~mm}$, as well as for $B=0 \mathrm{~mm}$. In total, eight junctions were analyzed. For each of them, several positions of the window in a cavity wall were considered. When modeling temperature fields, sections of the wall with a width of approximately 2 wall thicknesses were included. Simulation examples performed by the authors showed that at this distance from the node, the isotherms become parallel. This suggests that the heat flow is directed perpendicular to the wall surface. Further increasing the wall width does not change the temperature fields of the nodes.

As a result of the calculations, the tabular dependences of the critical point temperature on the nine values of the external air temperature and on the placement of the window frame in a cavity wall are obtained. The location of the window block is set by the distance, $X$, shown in Figure 2 from the initial position of the window in Figure 1.

\section{RESEARCH RESULTS AND THEIR ANALYSIS}

The obtained dependences are represented by graphs in Figures 3-5. Each of the graphs contains a series of curves that shows the temperature changes of the internal jamb depending on the displacement of the window frame. The corresponding outside air temperature is indicated next to each curve.

The horizontal dotted line in all the graphs corresponds to a dew point temperature of $+10.7^{\circ} \mathrm{C}$ for an indoor air temperature of $+20^{\circ} \mathrm{C}$ and a relative humidity of $50 \%$. Such design parameters are set by the design standards of Ukraine [1] for the microclimate of residential buildings and are close to the requirements of other European countries. The intersection of this line with the curve, indicating the temperature of the outside air, gives the value of the window displacement in the cavity wall at which no condensation will form on the surface of the internal jamb. If necessary, these graphs allow taking into account other dew point temperatures and other outdoor air temperatures by interpolating between the existing curves.

Figure 3 shows the results of the analysis of the walls made of solid ceramic bricks with a thickness of 510 $\mathrm{mm}$. The junction of the window frame to the uninsulated brick wall when installing the window in the starting position, as shown in Fig. 1, has a sufficient level of thermal reliability by the criterion of condensate formation with outside air temperatures above $-13^{\circ} \mathrm{C}$. At an outdoor air temperature of $-15^{\circ} \mathrm{C}$, the window must be shifted by the $30 \mathrm{~mm}$ inside the room, and at an outdoor air temperature of $-20^{\circ} \mathrm{C}$, a $120-\mathrm{mm}$ shift is required. At outside air temperatures below $-22^{\circ} \mathrm{C}$, it is impossible to ensure a sufficient level of thermal reliability owing to the displacement of the window frame. The presence of facade insulation significantly increases the level of thermal reliability of the unit. The graphs in Figure 3 show that with insulation thickness of $B=50 \mathrm{~mm}$ and the installation of the window close to the outside brick casing, condensate is not formed in the junction at outside air temperatures above $-22^{\circ} \mathrm{C}$. Further increase in the thermal insulation layer thickness to $100 \mathrm{~mm}$ and $150 \mathrm{~mm}$ ensures reliable operation of the unit at outside air temperatures higher than $-24^{\circ} \mathrm{C}$ and $-25^{\circ} \mathrm{C}$. The displacement of the window frame inside allows it to operate at lower outdoor temperatures. Depending on the insulation thickness and the design outside air temperature, the shift by $X=120-150 \mathrm{~mm}$ raises the temperature in the critical area of the junction в by up to $3^{\circ} \mathrm{C}$. Even with the maximum possible displacement of the window by $X=150 \mathrm{~mm}$ and the insulation thickness of $B=150 \mathrm{~mm}$, the unit does not provide sufficient thermal reliability 
Providing the thermal reliability of window junctions during the thermal modernization of civil buildings

with an outside air temperature lower than $-34{ }^{\circ} \mathrm{C}$. The similarity of the graphs in Figure 3 at $B=100 \mathrm{~mm}$ and $B=150 \mathrm{~mm}$ indicates that a further increase in the insulation layer thickness will not significantly increase the temperature in the critical area of the junction and will not increase its thermal reliability by the criterion of condensation.
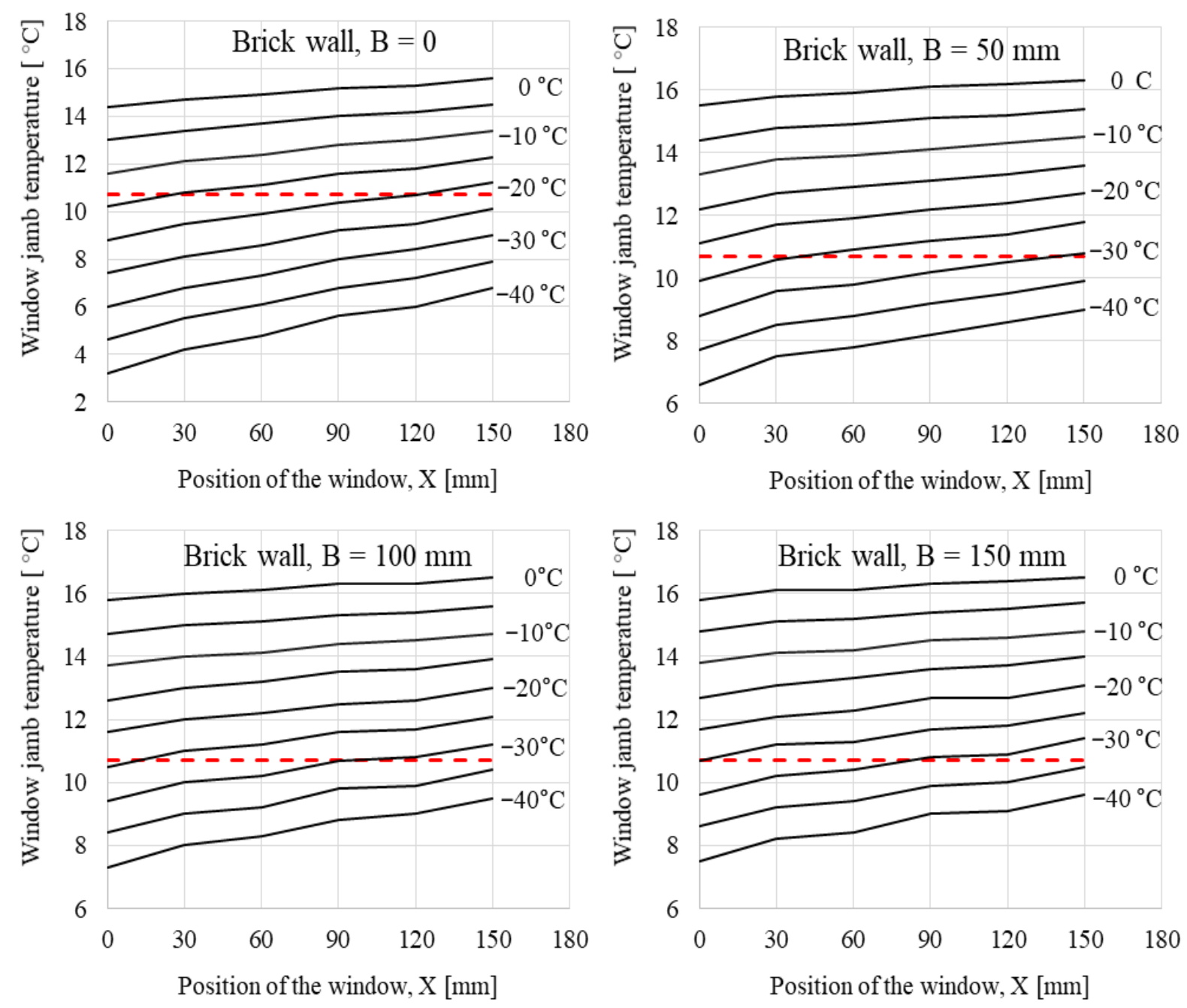

Figure 3 Temperatures in the critical zones of the brick wall junctions

It is possible to increase the level of thermal reliability of the junctions by replacing the window frame with a less heat-conducting structure or with additional insulation of the external or internal jamb. Insulation of the external jamb is impossible owing to the presence of an external casing, which partially covers the window frame and leaves no room for a layer of an insulating material, as shown in Figures 1 and 2 . Window blocks with a 70$\mathrm{mm}$ PVC structure is quite popular nowadays, and therefore, its replacement is impractical. Using the same method, calculations of brick wall junctions and internal jambs made of mineral wool slabs were performed. The insulation layer thickness at the junction with the block frame window was $30 \mathrm{~mm}$.

The results of the calculations are presented in Figure 4. A comparison of the graphs in Figures 3 and 4 shows that the insulation of the internal jamb raises the temperature in the critical area by $1-3^{\circ} \mathrm{C}$. This allows to use such a constructive solution with outdoor temperatures up to $-40{ }^{\circ} \mathrm{C}$, provided the window is displaced inside the room by $150 \mathrm{~mm}$. 

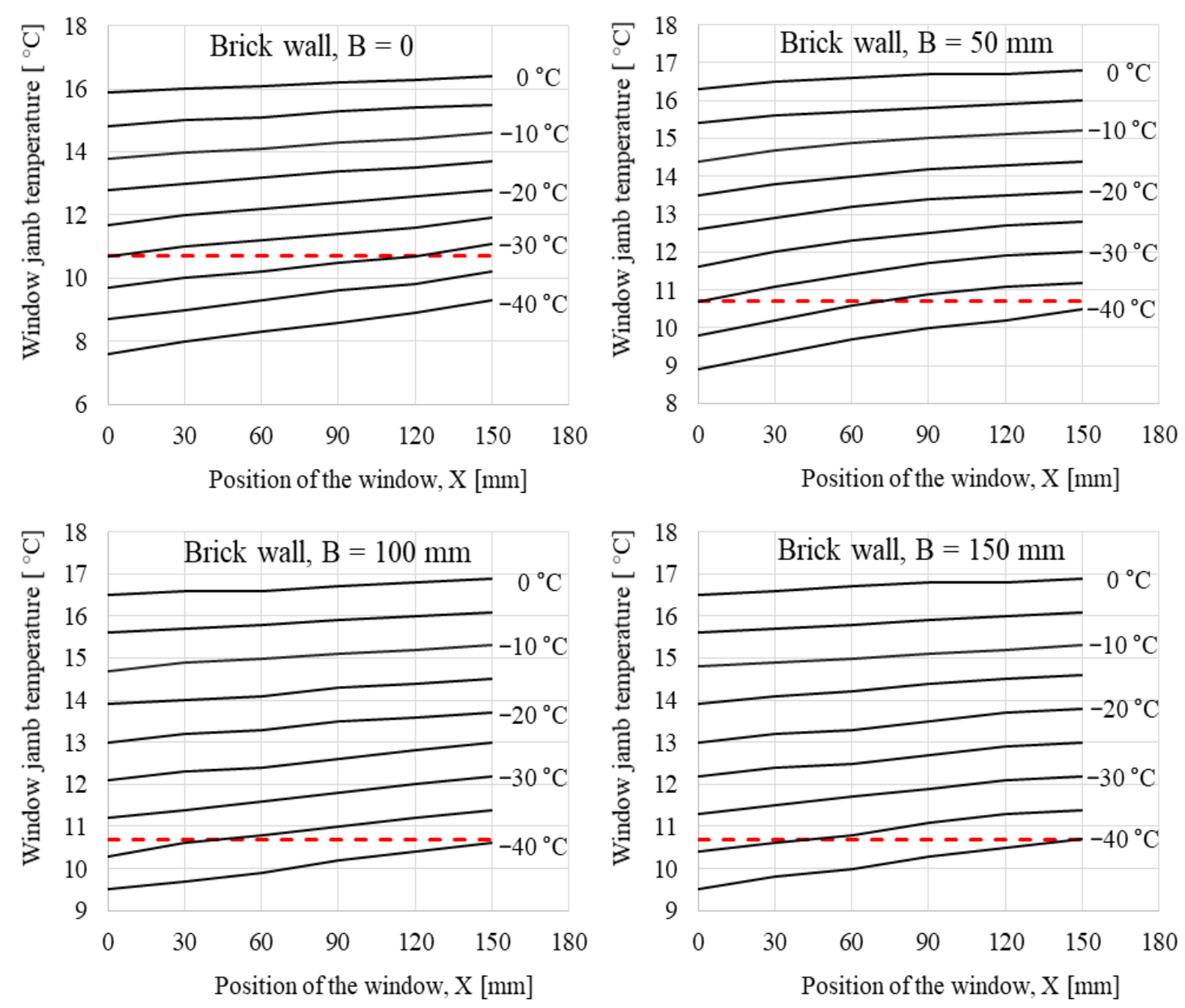

Figure 4 Temperatures in the critical zones of the brick wall junctions with insulated internal jambs

The analysis results of the temperature regime of the window frame junction to precast expanded clay concrete walls with a thickness of $300 \mathrm{~mm}$ are presented in Figure 5 . When installing the window frame at a distance of $25 \mathrm{~mm}$ from the outer wall edge without additional insulation, this junction has a sufficient level of thermal reliability at outside temperatures above $-14^{\circ} \mathrm{C}$. Shifting the window inside the room at a distance of 100 $\mathrm{mm}$ from the outer edge of the wall expands the temperature range of operation to $-19^{\circ} \mathrm{C}$. These values are close to the values shown in Figure 3 for the uninsulated brick wall. Insulation of the outer surface and the jamb of the wall with 50-mm mineral wool slabs significantly increases the level of thermal reliability. Such a unit can be operated at outside air temperatures up to $-33^{\circ} \mathrm{C}$. Shifting the window by $X=100 \mathrm{~mm}$ inside the room guarantees the absence of condensate on the surface of the internal jamb at outside temperature not lower than $-36{ }^{\circ} \mathrm{C}$. Insulation with thicknesses of $B=100$ and $B=150 \mathrm{~mm}$ allow to normally operate the node of the window side junction to the precast expanded clay concrete wall at temperatures $-40^{\circ} \mathrm{C}$ and $-42^{\circ} \mathrm{C}$. To do this, the window must be installed at a distance of $X=100 \mathrm{~mm}$ from the outer edge of the precast expanded clay concrete wall.

It is worth noting the dependence of the temperature in the critical zone of the insulated unit on the displacement of the window. It is considered, the decrease in this temperature at displacements up to $50 \mathrm{~mm}$ increases the area of heat transfer to the outside air. With a further shift in the window, heat losses through the facade decrease owing to the removal of the window from the outer wall surface. 

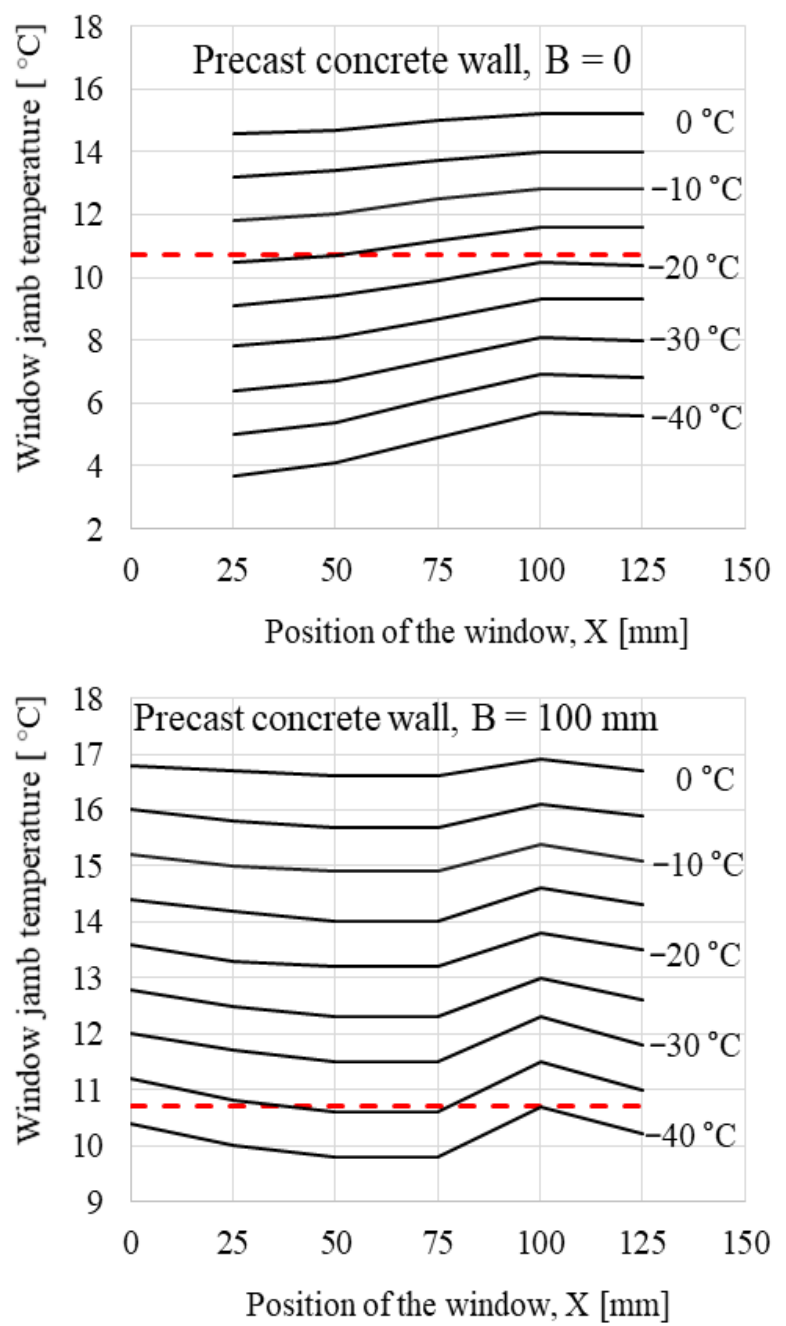
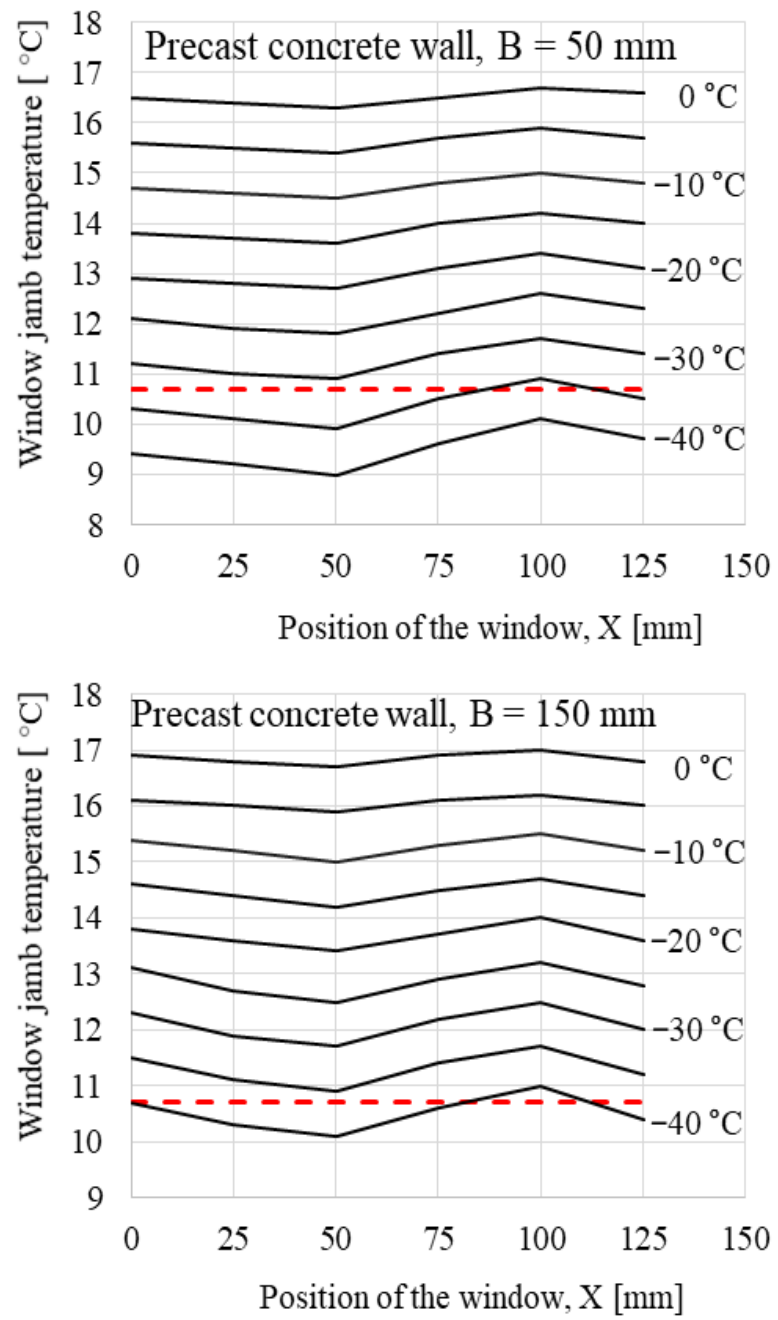

Figure 5 Temperatures in the critical zones of the precast concrete wall junctions

Graphs from Figures 3-5 allows the selection of the desired position of a window frame in a cavity wall during the thermal modernization of an existing building with brick and precast concrete walls, which were erected in the second half of the last century in many European countries. This requires the following:

- depending on the climatic conditions and the regulatory requirements for the heat transfer resistance, the required thickness of the thermal insulation layer and the corresponding graph from Figures 3-5 are selected;

- based on the air temperature and humidity in the room, the dew point temperature is set, and the corresponding horizontal line is drawn on the selected graph (in Figures $3-5$, the dotted line indicates the dew point temperature of $+10.7^{\circ} \mathrm{C}$ );

- depending on the building area, the design value of the outside air temperature and the corresponding curve line in the graph in Figures $3-5$ are set;

- the position of the block frame window at which the critical point temperature of the node (curve in Figures 35 ) is above the horizontal line indicating the dew point is selected.

If necessary, it is possible to perform an approximate graphical interpolation between the curves indicating different outdoor temperatures. For example, it follows from Figure 3 that in a brick wall with a 100-mm insulation layer, an outside air temperature of $-28^{\circ} \mathrm{C}$ and a dew point temperature of $+10.7^{\circ} \mathrm{C}$, a block frame window should be shifted from its original position by $70-80 \mathrm{~mm}$ into the building. 


\section{SUMMARY}

1. In order to evaluate the thermal reliability by the criterion of condensate formation, the analysis of the temperature regime of metal-plastic window frame side junctions to brick and precast concrete walls of residential and public buildings was conducted. These buildings were massively erected in the second half of the last century and continue to operate nowadays. The decisive factor is the temperature of the critical zone of the inner surface window jamb, which must be not less than the dew point temperature. This temperature can be adjusted by shifting the window frame in the cavity wall inside the room.

2. Graphical dependences of the temperature in the critical zones of various design junctions on the temperature of the outdoor air and the displacement of the window frame inside the room are obtained. Comparison with the dew point temperature allows to determine the window displacement needed, which guarantees the absence of condensate on the surface of the internal window jamb.

3. In the initial state without additional insulation, the nodes of the brick and precast concrete walls can normally operate at the temperatures of the external air, higher than $-13^{\circ} \mathrm{C}$. The maximum possible displacement of the window frame inside the room expands the temperature range of the normal operation of the uninsulated brick walls to $-22^{\circ} \mathrm{C}$ and of the uninsulated precast concrete walls up to $-19^{\circ} \mathrm{C}$.

4. Facade insulation with $50-\mathrm{mm}$ mineral wool slabs significantly increases the temperature of the critical zone of the considered junctions and allows to operate at much lower design temperature of the external air. Further increase in the thermal insulation thickness to $100 \mathrm{~mm}$ and $150 \mathrm{~mm}$ has lesser impact on the temperature of the critical areas and the level of thermal reliability by the criterion of condensate formation.

5. A 100-150 mm thickness of the insulation and the displacement of the window frame inside the room by $100 \mathrm{~mm}$ guarantee the thermal reliability of the window frame and the concrete wall junctions at the design outdoor air temperatures of $-40^{\circ} \mathrm{C}$ and higher. This temperature range covers all the European countries except the colder Scandinavian ones.

6. With proper wall insulation and rational position of the window frame, the junction between a window and a wall can be safely operated at design temperatures of outside air of $-34^{\circ} \mathrm{C}$ and higher. Operation at temperatures up to $-40^{\circ} \mathrm{C}$ is possible by additional insulation of internal window jambs.

\section{References}

[1] DBN V.2.6-31:2016: Teplova izoliatsiia budivel. - K.: Ministerstvo budivnytstva Ukrainy, 2016. - 31 p. (in Ukrainian)

[2] Ahmed, K.; Carlier, M.; Feldmann, C.; Kurnitski, J. 2018: A new method for contrasting energy performance and near-zero energy building requirements in different climates and countries, Energies, 11 (6), 1334. https://doi.org/10.3390/en11061334

[3] Košir, M.; Pajek, L.; Hudobivnik, B.; Dovjak, M.; Iglič, N.; Božiček, D.; Kunič, R. 2017: Non-stationary thermal performance evaluation of external façade walls under Central European summer conditions. ISES Solar World Congress 2017, International Solar Energy Society, pp. 1-10.

[4] Ekström, T.; Blomsterberg, A.. 2016: Renovation of Swedish single-family houses to passive house standard-Analyses of energy savings potential, Energy Procedia, 96, pp. 134-145. https://doi.org/10.1016/i.egypro.2016.09.115

[5] Rockwool Frontrock MAX Plus. Kontaktne fasade. TEHNIČKI LIST 2018-07-HR. https://www.rockwool.hr/pregled-svih-proizvoda/fasade-hr/kontaktne-fasade/hr-frontrock-MaxPlus/?selectedCat=bro\%C5\%A1ure\%20i\%20katalozi Accessed 28 December 2020

[6] Putzträgerplatte Coverrock Technisches Datenblatt. FÜR DEN FACHBETRIEB/FACHMANN. AUSGABE 06/2019.https://www.rockwool.com/siteassets/rw-d/datenblatter/aubenwand-wdvs/db-coverrockrockwool.pdf?f=20190710090649 Accessed 28 December 2020

[7] Tsikaloudaki, K.; Laskos, K.; Bikas, D. 2012: On the establishment of climatic zones in Europe with regard to the energy performance of buildings, Energies, 5 (1), pp. 32-44. https://doi.org/10.3390/en5010032

[8] The critical importance of building insulation for the environment. European insulation manufacturers association: https://www.eurima.org/uploads/Modules/Mediacentre/brochure en.pdf Accessed 28 December 2020 
[9] Fertelli, A. 2013: Determination of optimum insulation thickness for different building walls in Turkey. Transactions of FAMENA, 37 (2), pp. 103-113.

[10] Duman, Ö. et al. 2015: A study on optimum insulation thickness in walls and energy savings based on degree day approach for 3 different demo-sites in Europe, In Proceedings of International Conference CISBAT 2015 Future Buildings and Districts Sustainability from Nano to Urban Scale. No. CONF. LESO-PB, EPFL, 2015.

[11] Kaynakli, Ö.; kaynakli, F. 2016: Determination Of Optimum Thermal Insulation Thicknesses For External Walls Considering The Heating, Cooling And Annual Energy Requirements, Uludağ University Journal of The Faculty of Engineering, 21 (1), pp. 227-241.

[12] Barrau, J.; Ibanez, M.; Badia, F. 2014: Impact of the insulation materials' features on the determination of optimum insulation thickness, International Journal of Energy and Environmental Engineering, 5(2-3), 79. https://doi.org/10.1007/s40095-014-0079-3

[13] Markova, J.; Athanasopoulou, A.; Sousa, M. L.; Dimova, S.; Pinto, A.; lannaccone, S. 2019: State of harmonised use of the Eurocodes. Publications Office of the European Union, 2019.

[14] EN 1991-1-3 (2003): Eurocode 1: Actions on structures - Part 1-3: General actions - Snow loads.

[15] DSTU-N B V.1.1-27:2010 Zakhyst vid nebezpechnykh heolohichnykh protsesiv, shkidlyvykh ekspluatatsiinykh vplyviv, vid pozhezhi. Budivelna klimatolohiia, Kyiv, 2010. (in Ukrainian)

[16] European climate zones and bio-climatic design requirements. Project report BEAR-iD, Nobatek 2016. 31 p.

[17] Azmy, N. Y.;Ashmawy, R. E. 2018: Effect of the Window Position in the Building Envelope on Energy Consumption, International Journal of Engineering \& Technology, 7(3), pp. 1861-1868. https://doi.org/10.14419/ijet.v7i3.11174.

[18] Stolarska, A.; Strzałkowski, J.; Garbalińska, H. 2018: Using CFD software for the evaluation of hygrothermal conditions at wall-window perimeters, IOP Conference Series: Materials Science and Engineering, 415, pp. 1-8. https://doi.org/10.1088/1757-899X/415/1/012046.

[19] Sierra, F.; Gething, B.; Bai, J.; Maksoud, T. 2017: Impact of the position of the window in the reveal of a cavity wall on the heat loss and the internal surface temperature of the head of an opening with a steel lintel, Energy and Buildings, 142, pp. 23-30. https://doi.org/10.1016/i.enbuild.2017.02.037.

[20] Pashynskyi V.A.; Nastoiashchyi V.A.; Dzhyrma S.O.; Plotnikov O.A.; Ostapchuk A.S. 2017: Vplyv polozhennia vikonnykh blokiv po tovshchyni stiny na teplotekhnichni kharakterystyky vuzla yikh prymykannia, Sciences of Europe, 3 (21), pp. 8-13. (in Ukrainian)

[21] THERM 2.0 Program Description. Berkeley CA 94720 USA, 1998. https://windows.lbl.gov/sites/default/files/Downloads/therm2.pdf Accessed 28 December 2020

Please cite this article as: Pashynskyi, M.; Dzhyrma, S.; Pashynskyi, V.; Nastoyashchiy, V.: Providing the thermal reliability of window junctions during the thermal modernization of civil buildings, Electronic Journal of the Faculty of Civil Engineering Osijek-e-GFOS, 2020, 21, pp. 45-54, https://doi.org/10.13167/2020.21.4 